\title{
EFFECTS OF STAPHYLOCOCCUS ALPHA-TOXIN AND STREPTOLYSIN S ON THE OXIDATION OF SUCCINATE BY ASCITES TUMOUR CELLS
}

\author{
Dorothy A. Symington AND J. P. Arbuthnott* \\ Department of Microbiology, The University of Glasgow
}

Ascites tumour cells provide a useful model for the study of the action of cytolytic toxins on whole cells. They possess a subcellular organisation that is absent from erythrocytes, and the ease with which they can be propagated presents a distinct advantage over tissue-culture cells. However, the abnormal aspects of the structure and metabolism of tumour cells must be borne in mind.

Both staphylococcus $\alpha$-toxin and streptolysin $S$ are known to be cytolytic for a number of cell types, including ascites tumour cells (see reviews by Bernheimer, 1968, and Arbuthnott, 1969). Toxin treatment of the latter results in gross morphological damage, leakage of compounds of small and large molecular weights from the cells and loss of their ability to proliferate in mice (Ginsburg, 1959; Ginsburg and Grossowicz, 1960; Madoff, Artenstein and Weinstein, 1963). Such effects are consistent with a primary action of these toxins on the cell membrane that leads to altered permeability. It is now generally accepted that most cytolytic toxins act by disorganising the cell membrane and the study of toxin-membrane interactions is a subject of intense current interest (Weissmann, Sessa and Bernheimer, 1966; Woodin and Wieneke, 1966 $a$ and $b$; Freer, Arbuthnott and Bernheimer, 1968). When considering the cytotoxicity of these agents, however, it also seems relevant to determine whether secondary metabolic changes occur within the cell.

It was decided, therefore, to compare the effects of two cytolytic toxins, streptolysin $S$ and staphylococcus $\alpha$-toxin, on the respiration of washed suspensions of Krebs 2 ascites tumour cells employing succinate as substrate. It emerged that these two toxins had essentially similar effects but differed substantially in their modes of action.

\section{MATERIALS AND METHODS}

\section{Propagation and treatment of ascites tumour cells}

Krebs 2 mouse ascites tumour cells were propagated by intraperitoneal injection of $0.2 \mathrm{ml}$ freshly aspirated ascitic fluid into Porton white mice (weighing 25-35 g) every 7 days. Cells for all experiments were harvested by needle aspiration from mice 7-10 days after injection. The cells were washed once with $7 \cdot 3$ per cent. polyvinylpyrrolidone (PVP) buffered with $0.02 \mathrm{M}$ tris- $\mathrm{HCl}$ buffer at $p \mathrm{H} \mathrm{7.3}$, and once in Ringer's solution and then resuspended to the original volume in PVP-tris buffer: the final concentration of cells varied between ( 1 and 2$) \times 10^{8}$ per $\mathrm{ml}$. Washing prevented spontaneous aggregation and made the cells suitable for manometric studies.

Disintegrated preparations of Krebs 2 cells were made by sonicating washed cells suspended in Ringer's solution with an MSE ultrasonic probe for $45 \mathrm{~s}$, after which 90 per cent.

Received 28 Mar. 1969; accepted 4 May 1969.

* Alan Johnston, Lawrence and Moseley Research Fellow of the Royal Society.

J. MED. MICROBIOL,--vol. 2 (1969) 
of the cells were disintegrated as assessed microscopically. These disintegrated cell preparations were still capable of oxidising succinate, indicating that mitochondrial function had been preserved.

\section{Toxin preparations}

Staphylococcus $\alpha$-toxin was prepared from Staphylococcus aureus (strain Wood 46, NCTC 7121) by a method devised by McNiven and Arbuthnott (unpublished). The organisms were grown in nutrient broth (Oxoid) at $37^{\circ} \mathrm{C}$ in a Gallenkamp shaking waterbath for $7 \mathrm{hr}$ and continually gassed with a mixture of 70 per cent. oxygen and 30 per cent. carbon dioxide. After centrifugation at 10,000 r.p.m. for $10 \mathrm{~min}$., the supernatant fluid was made 85 per cent. saturated with ammonium sulphate. The resulting precipitate was harvested and dissolved in one-twentieth of its original volume in $0.03 \mathrm{M}$ borate buffer at $p \mathrm{H} 8.3$. This concentrated toxin was passed through a DEAE A-50 Sephadex column and eluted with $0.03 \mathrm{M}$ sodium phosphate buffer at $p \mathrm{H} 6.5$. The $\alpha$-toxin peak was identified by screening fractions for haemolytic activity against rabbit erythrocytes. Fractions rich in $\alpha$-toxin were bulked and dialysed against 85 per cent. saturated $\left(\mathrm{NH}_{4}\right)_{2} \mathrm{SO}_{4}$; the resulting precipitate was harvested by centrifugation at $3000 \mathrm{r}$.p.m. for $10 \mathrm{~min}$, redissolved in 3-5 ml 0.03M borate buffer at $p \mathrm{H} 8 \cdot 3$ and dialysed against $0.03 \mathrm{M}$ borate buffer to remove residual $\left(\mathrm{NH}_{4}\right)_{2} \mathrm{SO}_{4}$. Such preparations had a potency of approximately 8000 haemolytic units (HU) per $\mathrm{ml}$ when titrated by the method described by Bernheimer and Schwartz (1963).

Staphylococcus $\delta$-toxin was prepared from a strain of Staphylococcus aureus isolated from a case of toxic epidermal necrolysis (Arbuthnott et al., 1969); the organism produced $\delta$-toxin and no detectable $\alpha$-toxin. Partially purified $\delta$-toxin was prepared by the first stage of the method of Wiseman and Caird (1968) and contained 160 HU per ml.

Streptolysin $S$ was prepared by a modification of the method described by Bernheimer (1949). Strain C203S of Streptococcus pyogenes was grown for $5 \mathrm{hr}$ in Difco Brain-Heart Infusion broth containing $0 \cdot 1$ per cent. maltose until the end of the logarithmic phase of growth was reached. The cells were harvested by centrifugation at 10,000 r.p.m. for $10 \mathrm{~min}$. and washed once in phosphate-buffered saline $(0.85$ per cent. sodium chloride with $0 \cdot 14 \mathrm{M}$

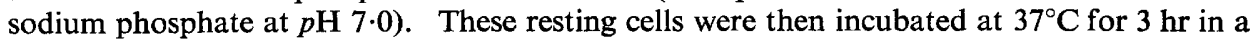
suspending medium prepared according to the method of Bernheimer (1949); this contained "Active Factor" (a ribonuclease-resistant yeast RNA core commercially prepared by Worthington Biochemicals Ltd, Freehold, New Jersey, USA). After they had been allowed to stand overnight at $4^{\circ} \mathrm{C}$, the cells were removed by centrifugation and the supernatant fluid was titrated against 0.8 per cent. human erythrocytes. Titres of between 3000 and 6000 HU per ml were consistently obtained.

\section{Manometric assays}

Respiration of ascites tumour cells and disintegrated cells was followed in the Warburg apparatus by measuring oxygen uptake. The substrate sodium succinate was present at a final concentration of $0.02 \mathrm{M}$ in each flask, which contained $(10-15) \times 10^{6}$ cells per $\mathrm{ml}$. The reaction volume was $3 \mathrm{ml}$ and flasks were shaken at 80-100 cycles per min. at $37^{\circ} \mathrm{C}$. PVPtris buffer was used to make up all solutions and all assays were carried out in duplicate. Control fluids included heat-inactivated toxin, neutralised toxin and the buffer used for dilution of the toxin.

\section{RESUltS}

It must be emphasised that the present paper deals only with effects on the oxidation of succinate. Succinate was chosen as substrate because it is oxidised by an enzyme complex (succinic oxidase) that forms an integral part of the mitochondrion. Thus, unlike other possible substrates, its metabolism does not require cytoplasmic enzymes or soluble cofactors. For this reason it seemed likely that succinate oxidation offered a relatively simple system for study. 


\section{Staphylococcus $\alpha$-toxin}

Purified staphylococcus $\alpha$-toxin had an immediate effect on the respiration of Krebs 2 ascites tumour cells when succinate was present as substrate. In each of 12 experiments the addition of $\alpha$-toxin caused a marked increase in the

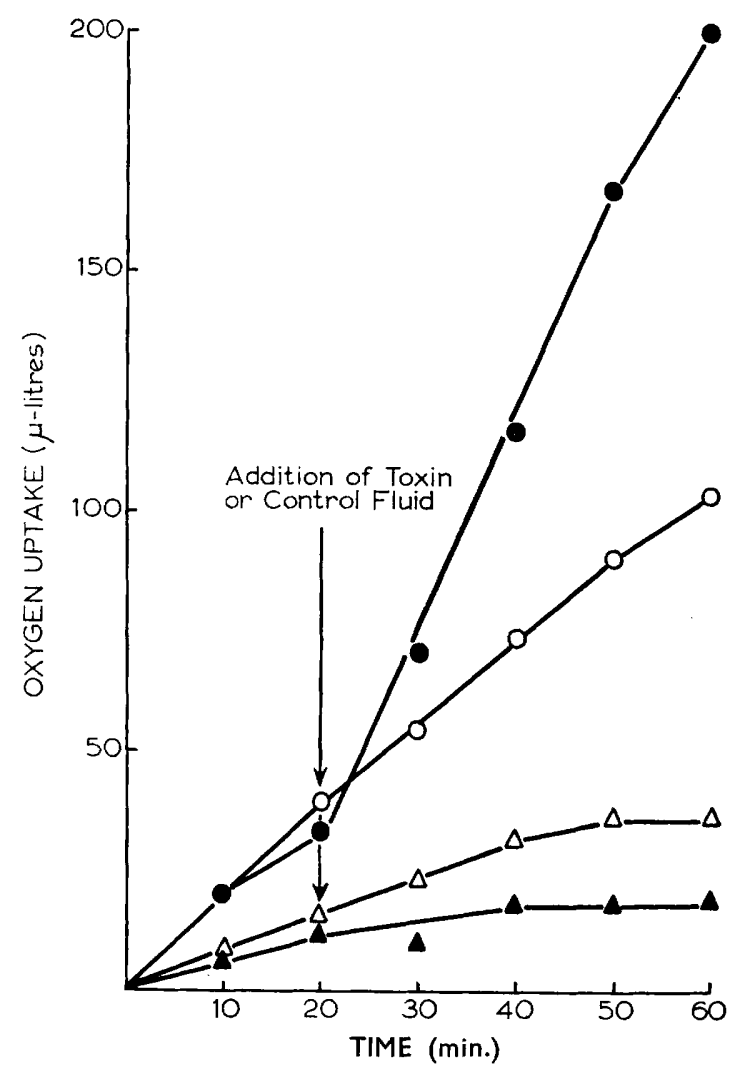

FIG. 1.-The effect of staphylococcus $\alpha$-toxin at a final concentration of $133 \mathrm{HU}$ per ml on the oxidation of succinate by Krebs 2 ascites tumour cells. $=$ Toxin added to cell suspension at $20 \mathrm{~min}$.; $\mathrm{O}-\mathrm{O}=$ control fluid added to cell suspension at $20 \mathrm{~min} ; \triangle \longrightarrow \triangle=$ endogenous respiration of control cell suspension; $\Delta-\boldsymbol{\Delta}=$ endogenous respiration of cell suspension treated with toxin at $20 \mathrm{~min}$.

rate of oxygen uptake by the cells (fig. 1). In addition to the immediate stimulation of the oxidation of exogenous sodium succinate there was also impairment of endogenous respiration by toxin. The degree of stimulation observed was not directly proportional to the concentration of $\alpha$-toxin. Above a threshold level of 6-12 HU per ml, fairly constant maximum stimulation was observed (fig. 2). With high concentrations of $\alpha$-toxin (greater than $200 \mathrm{HU}$ per $\mathrm{ml}$ ), the degree of stimulation was reduced in some experiments.

In order to establish that these effects were specific for staphylococcus $\alpha$-toxin, Krebs 2 cells were treated with an amount of $\alpha$-toxin just neutralised 
with an appropriate amount of commercially prepared $\alpha$-antitoxin (fig. 3). Neutralisation of the haemolytic activity of the $\alpha$-toxin also abolished the stimulation effect. In view of the recent work of Bernheimer, Avigad and Grushoff (1968) it was necessary to establish whether traces of $\delta$-toxin were responsible for the effect. The presence of normal, inactivated horse serum, in amounts known to inactivate the haemolytic activity of staphylococcus $\delta$-toxin, had no effect on stimulation. Furthermore the addition of $\delta$-toxin to actively respiring cells did not cause stimulation. These observations seem to exclude the possibility that the effect was due to small contaminating amounts of $\delta$-toxin

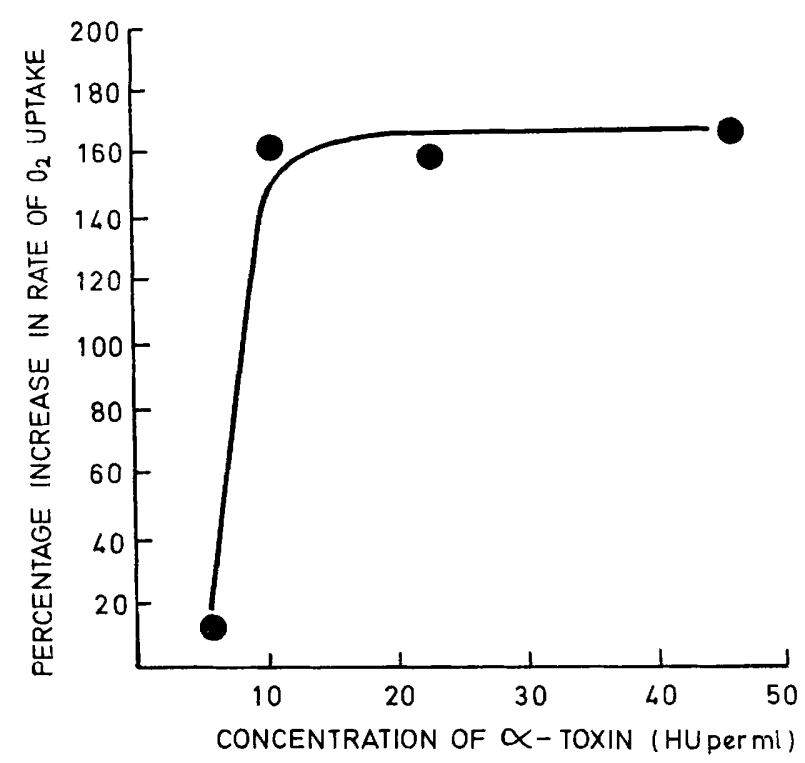

FIG. 2.-Relation between increased succinate oxidation and concentration of staphylococcus $\alpha$-toxin. The percentage increase in rate of $\mathrm{O}_{2}$ uptake for each toxin concentration was determined over a period of $20 \mathrm{~min}$. after the addition of $\alpha$-toxin to actively respiring cells.

in the $\alpha$-toxin preparation, and strongly suggest that the ability to stimulate respiration was a specific property of the staphylococcus $\alpha$-toxin.

In order to determine whether the effect of $\alpha$-toxin on ascites tumour cells was reversible or irreversible, a suspension of cells was pretreated with $\alpha$-toxin and then washed with PVP-tris buffer before being tested for respiration on succinate; cells so treated were also stimulated (fig. 4).

Interaction between toxin and Krebs 2 cells also led to a loss in the haemolytic activity of the toxin preparation; the reduction in haemolytic titre with increasing time of contact between cells and toxin is shown in fig. 5 . However, the possibility that $\alpha$-toxin was being inactivated by a product that leaked from damaged cells could not be excluded. A crude washed membrane fraction was therefore prepared by ultrasonically disrupting $5 \times 10^{8} \mathrm{Krebs} 2$ cells, removing the cell debris by centrifuging at 2000 r.p.m., harvesting the membrane fraction by centrifugation at 18,000 r.p.m. for $30 \mathrm{~min}$. and washing 
it in PVP-tris buffer. After $30 \mathrm{~min}$. interaction between the membrane fraction and $900 \mathrm{HU}$ of $\alpha$-toxin, an 80 per cent. reduction in haemolytic activity was observed. Thus, while enzymes released from damaged cells may well be capable of degrading toxic protein, this experiment suggests that $\alpha$-toxin can bind to the cell membrane with resulting inactivation.

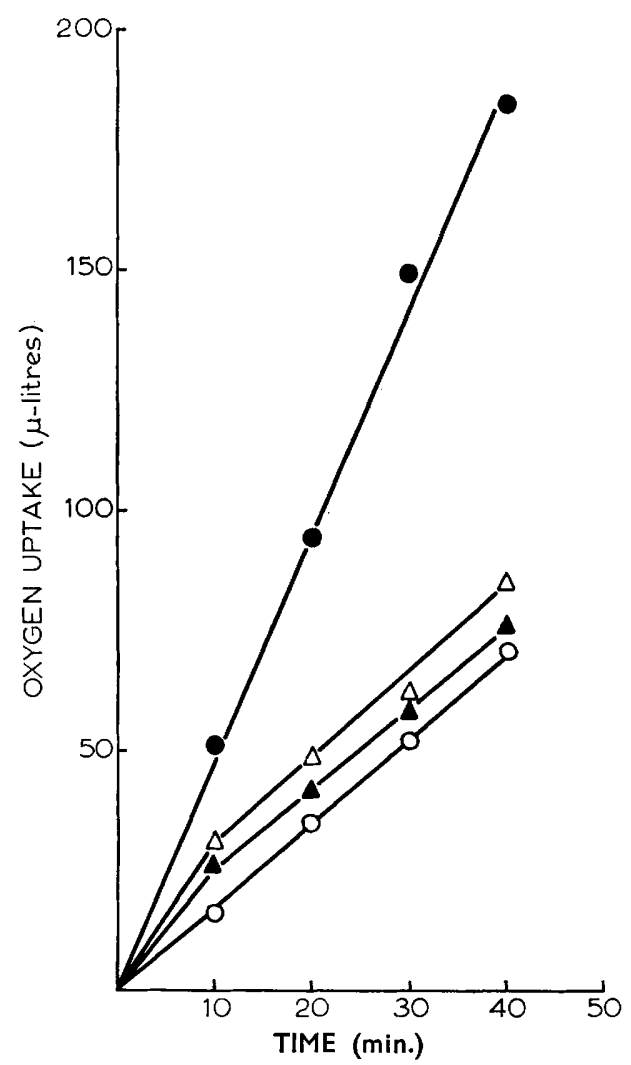

FIG. 3.-Neutralisation of the stimulation effect by $\alpha$-antitoxin. The cell suspensions were incubated with toxin, at a final concentration of $133 \mathrm{HU}$ per ml, with toxin-antitoxin mixture or with antitoxin alone for $30 \mathrm{~min}$. prior to addition of succinate. $=$ Cell suspension treated with $\alpha$-toxin; $\mathrm{O}-\mathrm{O}=$ control cell suspension with no additions; $\mathbf{A}-\mathbf{A}=$ cell suspension treated with toxin-antitoxin mixture; $\triangle \longrightarrow \triangle=$ control cell suspension treated with antitoxin alone.

It is known from previous work (Lominski et al., 1964) that highly purified staphylococcus $\alpha$-toxin has little or no effect on the respiration of isolated mammalian mitochondria. In view of the present findings it was decided to determine the effect of $\alpha$-toxin on the respiration of disrupted Krebs 2 cell preparations. From fig. 6 it can be seen that $\alpha$-toxin has no significant effect on succinic oxidase activity of such preparations. This suggests that the stimulation of respiration observed with toxin-treated cells is unlikely to result from the action of $\alpha$-toxin on mitochondria. 


\section{Streptolysin $S$}

Streptolysin $\mathbf{S}$ also stimulated the rate of oxygen uptake by Krebs 2 cells when sodium succinate was used as substrate (fig. 7). That this was not a nonspecific effect was shown by the fact that streptolysin $\mathrm{S}$ preparations, when heated at $100^{\circ} \mathrm{C}$ for $15 \mathrm{~min}$., lost both their haemolytic activity and the ability to stimulate the rate of succinate oxidation. However, the ascites tumour cells varied in their susceptibility to streptolysin $S$ to a much greater extent than in their susceptibility to staphylococcal $\alpha$-toxin. Indeed in 3 of 13 experiments

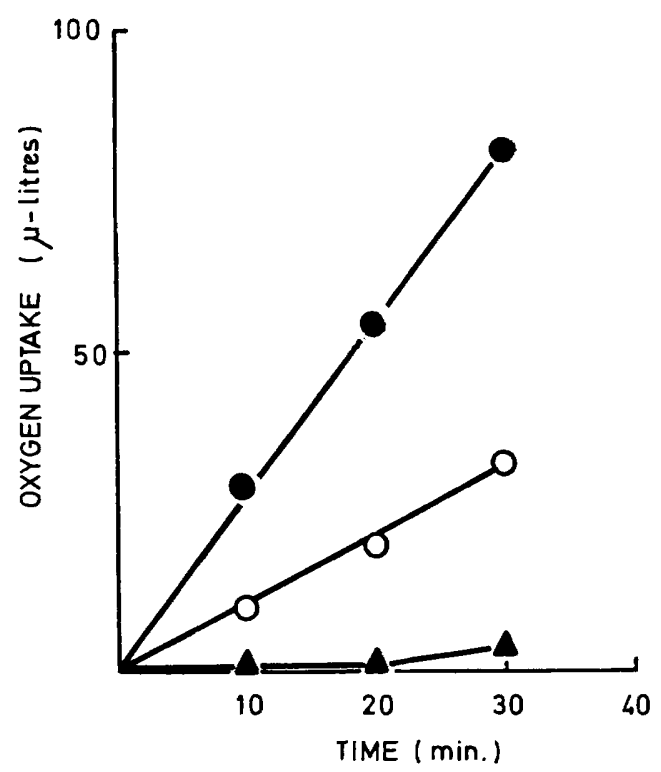

FIG. 4.-The effect of treating Krebs 2 ascites cells with staphylococcus $\alpha$-toxin for $30 \mathrm{~min}$. and then washing the cells prior to addition of succinate. $\alpha$-toxin (final concentration $133 \mathrm{HU}$ per $\mathrm{ml}$ ); endogenous respiration.

no stimulation was observed, even when very high concentrations of streptolysin $\mathrm{S}$ were employed. The reason for this variation in susceptibility is not known, but is not due only to minor differences in the ages of the cells. Because of this variability in response, a detailed study of the effect of varying concentrations of streptolysin S could not be carried out. However, in preparations of sensitive cells, concentrations of streptolysin S of at least $200 \mathrm{HU}$ per ml were required to cause stimulation.

Streptolysin S also differed from staphylococcus $\alpha$-toxin in that it did not affect actively respiring cells; a minimum period of 10 minutes' contact between washed cells and toxin prior to the addition of succinate was required to induce stimulation. Pre-incubation with toxin for longer than $10 \mathrm{~min}$. did not significantly influence the degree of stimulation. That the effect of streptolysin S was also irreversible is shown by the fact that Krebs 2 cells that had been pretreated for $30 \mathrm{~min}$. with streptolysin $\mathrm{S}$ at a concentration of $1000 \mathrm{HU}$ per $\mathrm{ml}$. 
and washed free of toxin prior to the assay, still exhibited 98 per cent. stimulation of oxygen uptake.

In contrast with the findings for staphylococcus $\alpha$-toxin, the haemolytic activity of streptolysin $\mathrm{S}$ was not significantly reduced by interaction between cells and toxin for periods of up to $60 \mathrm{~min}$. Thus it appears that streptolysin $\mathrm{S}$ is not bound to the ascites tumour cell membrane.

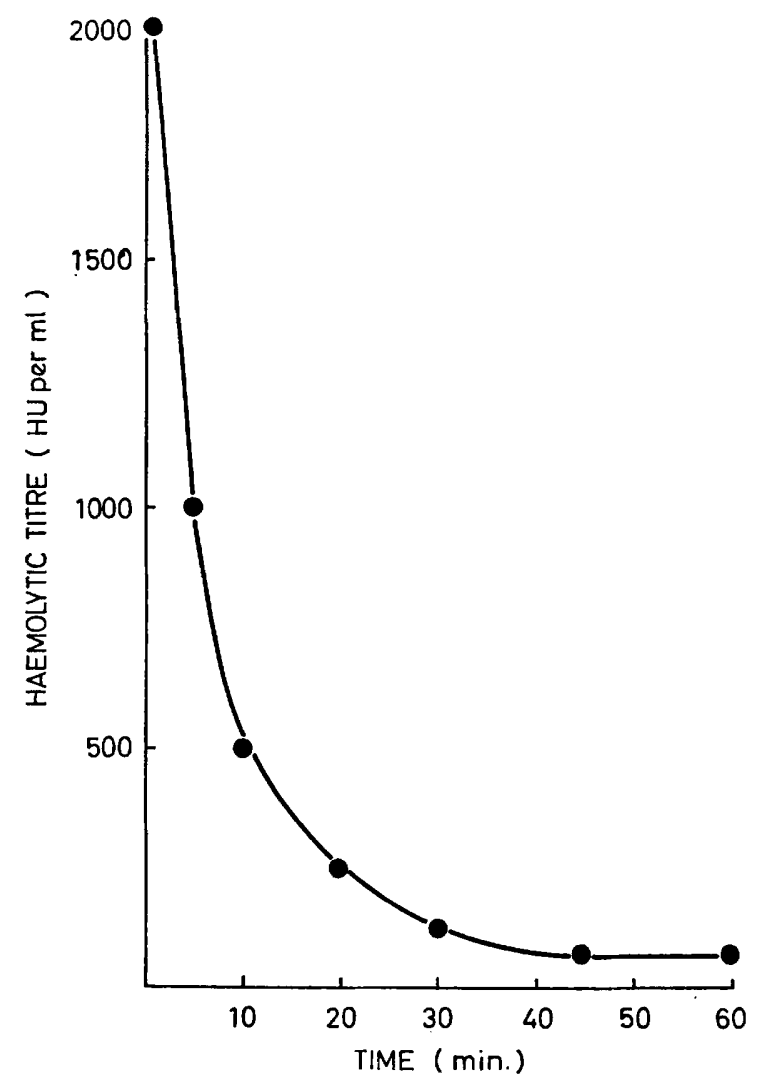

FIG. 5.-Inactivation of staphylococcus $\alpha$-toxin by Krebs 2 ascites cells. The $\alpha$-toxin titre of control incubation mixtures in which $\alpha$-toxin was mixed with the suspending fluid (tris-buffered PVP) showed no detectable reduction of haemolytic activity in the course of the experiment.

It seems unlikely that stimulation of respiration was due to a direct action on the mitochondria since it has been shown that streptolysin $\mathrm{S}$ inhibits both the succinic and cytochrome oxidase activity of isolated mouse liver mitochondria (Symington, Arbuthnott and Lominski, to be published). Disintegrated cell preparations were made as described above; streptolysin $\mathrm{S}$ inhibited succinic oxidase activity of such preparations (fig. 8). This finding indicates that the mitochondrial activity of Krebs 2 ascites tumour cells is impaired by streptolysin $\mathbf{S}$ and that the stimulation of succinate oxidation observed with whole cells is unlikely to be a result of the action of streptolysin S at the mitochondrial level. 


\section{Discussion}

It is clear from the present study that staphylococcus $\alpha$-toxin and streptolysin S can profoundly affect the metabolism of Krebs 2 ascites tumour cells. Although they differ in their detailed mechanisms, these two cytolytic agents resemble one another in that each can induce stimulation of cellular respiration as measured by the oxidation of exogenous succinate.

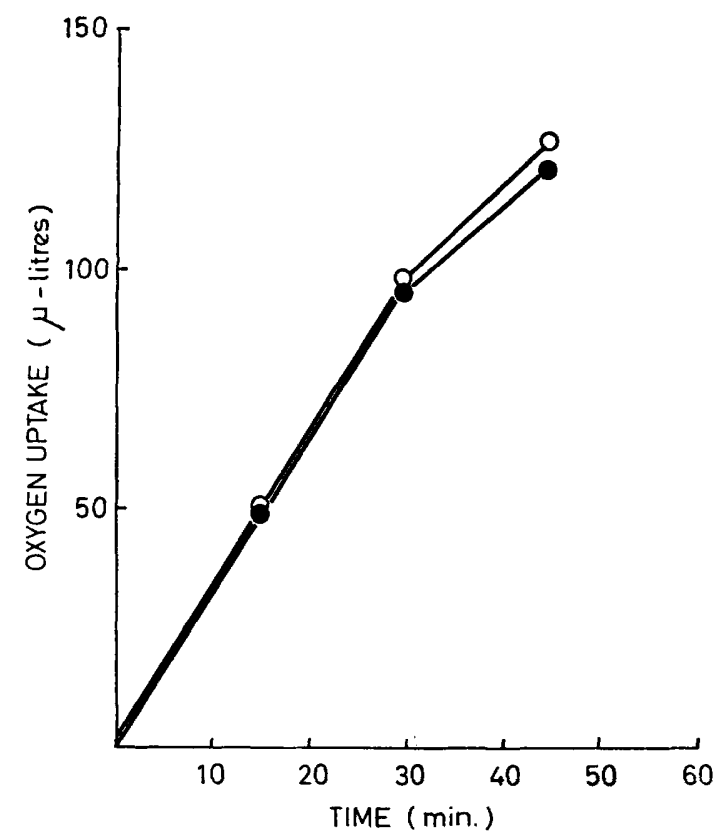

FIG. 6.-Action of staphylococcus $\alpha$-toxin, at a final concentration of $416 \mathrm{HU}$ per ml, on the oxidation of succinate by ultrasonically disintegrated Krebs 2 cells. $=$ Disintegrated preparation treated with toxin for $30 \mathrm{~min}$. prior to addition of succinate; $\bigcirc-\mathrm{O}=\mathrm{control}$ preparation with no toxin added.

In the case of staphylococcus $\alpha$-toxin, this effect is instantaneous even on actively respiring cells and probably results from irreversible damage of the cell membrane with consequently increased permeability to succinate. Since the toxin has no direct effect on mitochondrial activity, it appears that the observed stimulation results from the increased availability of succinate to the mitochondria. It should be emphasised that $\alpha$-toxin causes maximum stimulation at concentrations as low as $20 \mathrm{HU}$ per $\mathrm{ml}(=2 \mu \mathrm{g}$ per $\mathrm{ml})$. The observed stimulation therefore reflects damage to the cell membrane, but is only an indirect measure of this damage. It seems that the permeability barrier to succinate can be removed by small amounts of $\alpha$-toxin, allowing the mitochondria to metabolise at a maximum rate; thus increased amounts of toxin would not be expected to cause further stimulation.

The present findings agree with the observations of Freer et al. (1968) that $\alpha$-toxin can be inactivated as a result of contact with cell membranes. On the 


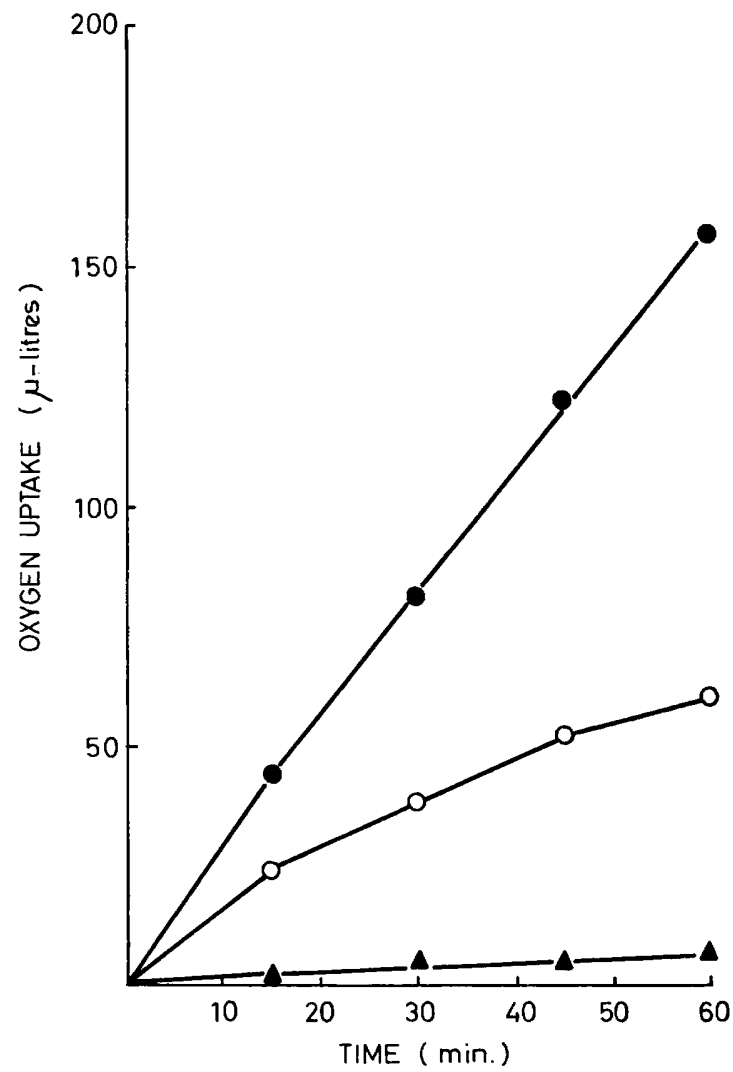

FIG. 7.- Increased succinate oxidation by Krebs 2 cells treated with streptolysin $\mathrm{S}$ at a final concentration of $2300 \mathrm{HU}$ per $\mathrm{ml}$ for $30 \mathrm{~min}$. prior to addition of succinate. cell suspension; $\mathrm{O}-\mathrm{O}=$ control suspension; $\boldsymbol{\Lambda}-\boldsymbol{\Lambda}=$ endogenous respiration.

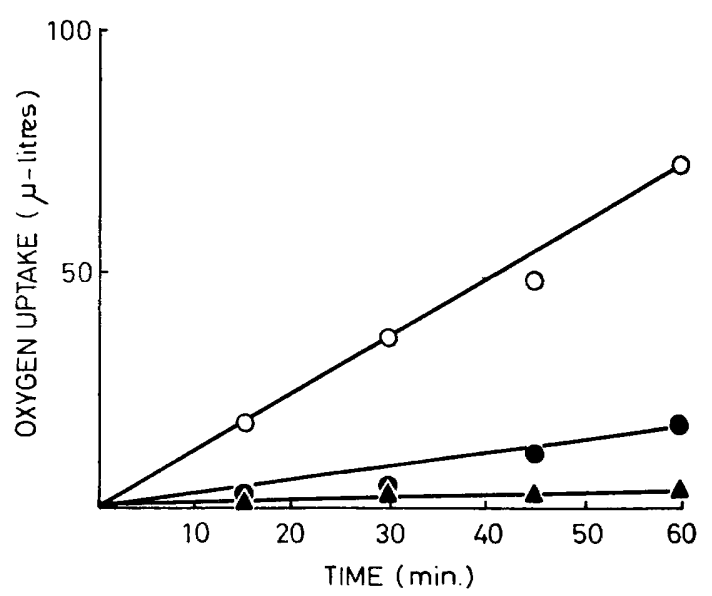

FIG. 8-Impairment of succinate oxidation of ultrasonically disintegrated Krebs 2 ascites cells by streptolysin S. The preparation was treated with streptolysin S at a final concentration of 1600 HU per $\mathrm{ml}$ for $30 \mathrm{~min}$. prior to the addition of succinate. $\mathrm{O}-\mathrm{O}=$ control preparation; $\Delta-\Delta=$ endogenous respiration. 
other hand, results of studies of the kinetics of haemolysis (Lominski and Arbuthnott, 1962; Marucci, 1963 $a$ and $b$; Cooper, Madoff and Weinstein, $1964 a$ and $b$ ) are consistent with a reversible enzymic interaction between $\alpha$-toxin and a component of the red cell surface. Thus an apparent contradiction exists between the results of kinetic studies and those obtained in experiments with artificial membranes, erythrocyte ghosts and Krebs 2 ascites tumour cells. Further study of the reaction between $\alpha$-toxin and Krebs 2 ascites tumour cells may yield valuable information about the detailed mechanism of toxin-membrane interactions.

The stimulation of succinate oxidation by streptolysin $\mathrm{S}$ can also be explained by increased permeability to succinate as a result of membrane damage. However, streptolysin S differs from staphylococcus $\alpha$-toxin in that it does not affect actively respiring cells. Therefore the actively metabolising ascites tumour cell is resistant in some way to the action of this toxin. These findings suggest that the point of attack of streptolysin S differs from that of staphylococcus $\alpha$-toxin. Moreover, the resistance of actively respiring cells may indicate that the substrate or receptor for streptolysin S can alter in configuration depending on the metabolic state of the cells. The different actions of these two cytolytic agents are further emphasised by the fact that streptolysin $\mathrm{S}$ is not inactivated during interaction with Krebs 2 ascites tumour cells.

It is also interesting that, although the mitochondrial activity of Krebs 2 ascites tumour cells is impaired by the action of streptolysin $S$ in cell-free preparations, this toxin does not impair the oxidation of succinate by intact cells; this seems to indicate little or no penetration of streptolysin S into the interior of the cell.

A detailed study of the effects of staphylococcus $\alpha$-toxin and streptolysin S on the morphology of Krebs 2 cells, by phase-contrast and electron microscopy is being undertaken and the results of these investigations will be presented separately.

\section{SUMMARY}

Small amounts of purified staphylococcus $\alpha$-toxin caused an immediate increase in the rate of succinate oxidation by Krebs 2 mouse ascites tumour cells. This effect appeared to be specific for $\alpha$-toxin and not to be due to contamination of the $\alpha$-toxin preparation with staphylococcus $\delta$-toxin. During interaction with Krebs 2 cells, the haemolytic activity of $\alpha$-toxin decreased by more than 95 per cent. Streptolysin-S preparations also caused increased oxidation of succinate, but only when washed cells were pretreated with toxin. These effects can be explained by postulating an action of the toxins on the cell membrane that leads to increased permeability to succinate. The different actions of staphylococcus $\alpha$-toxin and streptolysin $\mathrm{S}$ are discussed.

The authors gratefully acknowledge the help of Miss Christine McNiven of this department in preparing purified staphylococcus $\alpha$-toxin, and Dr R. H. Burdon and Miss Janet Smillie, Department of Biochemistry, University of Glasgow, for the gift of the Krebs 2 cell line. 


\section{REFERENCES}

Arbuthnott, J. P. . . . . . . . . 1969. In Microbial toxins, ed. by S. J. Ajl, T. C. Montie and S. Kadis, New York, vol 2, in press.

Arbuthnott, J. P., Gemmell, C. G., 1969. J. Med. Microbiol., 2, 479. KENT, J JNET, AND Lyell, A.

BERNHEIMER, A. W. . . . . . . . 1949. J. Exp. Med., 90, 373.

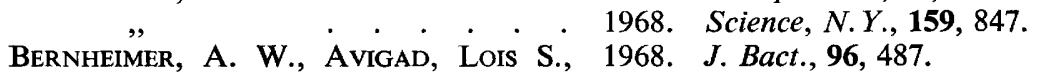
ANd Grushoff, Phyllis

Bernheimer, A. W., AND Schwartz, 1963. J. Gen. Microbiol., 30, 455. LoIs L.

COOPER, L. Z., MAdoff, M. A., AND 1964a. J. Bact., 87, 127. Weinstein, L.

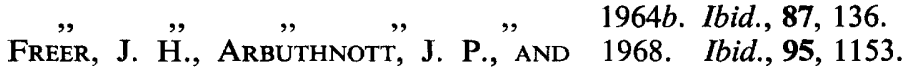
BERNHEIMER, A. W.

Ginsburg, I. . . . . . . . . . 1959. Br. J. Exp. Path., 40, 417.

Ginsburg, I., ANd Grossowicz, N. . . 1960. J. Path. Bact., 80, 111.

Lominski, I., AND ARBUthNotT, J. P. . 1962. Ibid., 83, 515.

Lominski, I., ARbuthnOTt, J. P., Gemmell, 1964. Lancet, 2, 503. C. G., Gray, S., AND Marshall, W. A.

Madoff, M. A., Artenstein, M. S., And 1963. Yale J. Biol. Med., 35, 382. WEINSTEIN, L.

MARUCCI, A. A. . . . . . . 1963a. J. Bact., 86, 1182.

WeIsSmanN, G., Sesssa, G., AND BERN- 1966. Science, N.Y., 154, 772. HEIMER, A. W.

Wiseman, G. H., and Caird, J. D. . . . 1968. Proc. Soc. Exp. Biol. Med., 128, 428.

Woodin, A. M., AND Wienteke, ANTon- 1966a. Biochem. J., 99, 469. NETTE A.

1966b. Ibid., 99, 479. 